NBER WORKING PAPERS SERIES

\title{
BANK EXPOSURE, CAPITAL AND SECONDARY MARKET DISCOUNTS ON DEVELOPING COUNTRY DEBT
}

\author{
Sule Ozler
}

Harry Huizinga

Working Paper No. 3961

\author{
NATIONAL BUREAU OF ECONOMIC RESEARCH \\ 1050 Massachusetts Avenue \\ Cambridge, MA 02138 \\ January 1992
}

We thank Trudy Cameron, Kenneth Froot and Kenneth Rogoff for many helpful comments. We have also benefitted from the comments seminar participants at U.C. Berkeley, Boston University, Brandeis, Harvard, MIT, Yale, and Stanford, and participants at the NBER Summer Institute. Sule Ozler gratefully acknowledges the support provided by the Debt and International Finance Division of the World Bank, and an NBER Ford Foundation Fellowship. Previous drafts of this paper were entitled "Secondary Market Prices for Developing Country Debt: The Role of Creditor Country Factors." This paper is part of NBER's research program in Intemational Studies. The findings, interpretations, and conclusions expressed in this paper are those of the authors and not those of the National Bureau of Economic Research or the World Bank, its Executive Directors or the countries they represent. 
NBER Working Paper \#3961

January 1992

\title{
BANK EXPOSURE, CAPITAL AND SECONDARY MARKE'T DISCOUNTS ON DEVELOPING COUNTRY DEBT
}

\begin{abstract}
Previous empirical studies of secondary market discounts for developing countries have ignored important creditor country factors. The empirical evidence in this paper indicates that, after controlling for repayment indicators of borrower countries, bank exposure and capital are important determinants of secondary market discounts: an increase in the exposure of large banks to a particular country leads to a decrease in the secondary market discounts on the debt of that country, while an increase in the capital of large banks leads to an increase in secondary market discounts. Among the repayment indicators of developing countries, only debt ratios are found to be significant determinants of the discounts. We suggest that the impacts of exposure and capital can be explained by the presence of deposit insurance. The evidence presented on the stock market pricing of lender banks supports this view.
\end{abstract}

Sule Ozler

Department of Economics

405 Hilgard Avenue

University of California

Los Angeles, CA 90024-1477

and NBER
Harry Huizinga

Department of Economics

Stanford University

Stanford, CA $9(0405$ 


\section{Introduction}

In the secondary market for developing country debt, lltaly loant tiade at large discounts. The magnitude of these discounts is considered to reflect a lack of confidence that the debts will ever be fully repaid, since secondary market prices are regarded as indicators of the value of the outstanding debt. In an attempt to understand the factors that influence the value of a country's outstanding debt empirical studies have primarily focused on economic characteristics of borrower countries that presumably affect their repayment prospects, such as GNP per capita, and the debt-to-exports ratio. ${ }^{1}$

Some puzzles concerning the patterns of secondary market discounts, however, remain to be explained: loans to countries with large commercial bank debt, such as Brazil and Mexico, sell at lower discounts than loans to smaller debtors; debt prices fell during the eighties, even though countries were making large repayments. Other developments of the period suggest that characteristics of the creditors could provide some explanations for these puzzles. In particular, during the eighties the position of comnercial banks changed substantially. Banks strengthened their capital, and engaged in significant amounts of interbank loan trading, changing the composition of

1 See for example Berg and Sachs (1989), Cohen (1988) Hajivassiliou (1988). Huizinga (1989), Sachs and Huizinga (1987). These variables are considered to be among the empirical measures suggested by the theoretical literature. For example seizure technology of the lenders, impitience of various parties, the importance of future credit market access are suggested as determinants of the value of dobt (see Eaton and Gersovitz (1981), and Bulow and Rogoff (1989b)). 
their loan portfolios. Interbank trading was in fact a very important component of trading in the secondary market. ${ }^{2}$

The objective of this paper is to betcer understand the determinants of secondary market discounts and provide an explanation for these puzzles. For this purpose, we focus on a set of factors omitted by existing studies of secondary market pricing of debt. In particular, we conduct an empirical analysfs to determine if the degree of exposure and the size of the regulatory capital of the lender banks have an impact on secondary market discounts. We consider the largest nine US banks. The data for exposure of these banks to individual countries and their total capital are quarterly for the period of 1986-1988. There are 41 countries in the sample, and the debt of 21 of these countries has been traded in the secondary market. In order to address potential problems due to sample selection we use a one step maximum likelihood estimation procedure. In the estimation process we attempt to control for countries' repayment prospects by using economic indicators of borrower countries, in particular, their debt ratios.

Our primary findings are that bank exposure and capital are indeed important determinants of discounts. The impacts of these variables are substantial and they explain a significant component of the variation of discounts across countrics and over time. Specifically, a 4.1 billion 1986 US dollars increase in the exposure of the large banks to a country is estimated to reduce discounts by more than 10 cents on the dollar. 3 A 2.7 billion

2698 of all trading activity in 1986 was interbank trading, compared to 358 in 1988. Source:Quarterly Review on Financial Flows to Developing Countries (1989).

3 We consider the largest nine US banks (size is measured by asset value). The sample mean of exposure to the 21 countries with craded debts is 2.7 bilition in 1986 dollars, with a standard deviation of 4.1 . The mean of 
1986 US dollars increase in the capital of the largest U.S. banks is found to increase discounts by nearly is cents on the dollar. The only borrowing country repayment indicators that systematically have a statistically significant. impact on discounts are various measures of the debt ratio, such as debt to exports and debt to GNP.

We suggest that bank deposit insurance provides an explanation for our results. Deposit insurance premia are flat rate premia and in particular do not reflect the riskiness of a bank's asset portfolio. Hence, deposit insurance encourages risk taking. Banks' incentives to take risk decrease with their rate of capitalization, since the expected subsidy from the deposit insurance agency is reduced. This suggests that increased exposure to a country leads to a decline (increase) in the secondary market discounts (prices), and that increased capitalization leads to an increase in secondary market discounts. This view appears consistent with the evidence for the period. In particular, the smaller regional banks (which are typically better capitalized) used the secondary market to reduce their developing country exposure.

The negative relationship between bank exposure and secondary market discounts could stem from the behavior of the multilateral lending agencies and large creditor country governments. Since these institutions are concerned with financial stability, they may provide loans to especially large borrowers to enhance their repayment prospects. While we cannot rule out this alternative by an investigation of secondary market pricing, we provide evidence from the stock market that favors the deposit insurance explanation.

discounts for this group is 47.35 with a stadard deviation of 22.7 . The average capital aggregate of the large banks over the 1986-88 period is 47 billion 1986 US dollars, with a standard deviation of 2.7 . 
Alternatively, large banks may be argued simply to have chosen to lend to the higher quality borrowers in the first place, or they may have chosen to syndicate a smaller share of high quality loans. Our results, however, are obtained after controlling for creditworthiness indicators of borrowers. In particular, we are careful to control for alternative measures of debt ratios, such as debt-to-exports, and debt-to-GNP.

The remainder of this paper is organized as follows. Section 2 contains the empirical investigation of secondary market discounts. Section 3 provides a discussion of potential explanations of the empirical findings as well as an evaluation of evidence on the stock market valuation of bank assets. Section 4 concludes.

\section{Do Bank Exposure and Capital Affect Secondary Market Discounts?}

\subsection{Methodology}

In the secondary market for developing country loans, debts of only some countries have been traded. The discounts on loans are observed for those countries with debts traded in this market. This suggests that a sample selection model is the correct specification of the determination of discounts." We leave the discussion of the explanatory variables and the sample characteristics to the next section, and first describe the selection model consisting of the following equations:

$$
D=\gamma x+u_{1}
$$

- If instead ordinary least squares is used the resulting estimates could be biased. 
where D - discount in the secondary market. Discount is defined as (1price), where price is the secondary market price of $\$ 1$ of debt.

$\lambda$ - variables relevant for the pricing of debt in the sccondary inarket.

$u_{1}$ - error term.

Discounts are observed when an underlying variable $T *$ crosses soine threshold as described in the following model:

$$
T^{*}-\beta X^{*}+u_{2}
$$

where $T^{*}$ - a latent varlable such that if $T *>0$ we observe trading at a discount in the secondary market, but if $T \star \leq 0$ we do not observe trading $\mathrm{at}$ a discount in the secondary market,

$x^{*}$ - variables that determine the occurrence of trading in the secondary market, possibly different from $X$ above,

$u_{2}=$ error term.

This nodel is a standard sample selection model, where the error terms are assumed to have a bivariate normal distribution, with standard deviations $\sigma_{1}$ and $\sigma_{2}$ and with covariance $\sigma_{12}^{2}$ (where $\rho^{2}-\sigma_{12}^{2} / \sigma_{1} \sigma_{2}$ )..$^{3}$ We estimate this model in one step maximum likelihood procedure. The identification condition for the equations require that as below there be one element of $X^{\prime}$ that is not in $x$. Alternatively, one could rely on the nonlinearity of the fitted probabilities in the selection equation to identify the parameters of the node 1 .

\subsection{Specification and Data}

The Impact of bank exposure and bank capital on the secondary market discounts is investigated using the discount equation (1) and the problt specification of trading in the secondary market as described in equation (2).

5 See Heckman (1979) for a discussion of selection models. 
Our data consists of quarterly information on 41 developing countries, based on data avallability, for the period of 1986-88. The debts of 21 countries were traded at a discount. In this section we discuss the variables and the data used in this analysis.

Equation (1) is a reduced form specification of the equilibrium prices in the secondary market. Hence, the explanatory variables should incorporate all the exogenous factors influencing lender and borrower behaviour. These include pertinent economic indicators of borrower countries, which have been used in several empirical studies addressing various issues concerning developing country debt. ${ }^{6}$ The borrowing country indicators are attemtps to measure the variables suggested by the theoretical literacure such as costs a defulting country suffers. A typical set of these indicators includes: debtto-exports ratio, reserves-to-imports ratio, real GNP per capita, and the rate of inflation. Our base specification use these variables as country indicators.' This study introduces bank exposure and bank capital variables into this equation.

In principle, some of the explanatory variables could be correlated with the error term. For example, the exposure variable may be endogenous since large discounts could affect the exposure of banks if write-offs are taken. Real GNP per capita, and reserves-to-GNP could also be correlated with the error term. To address this problem we used one quarter lagged values of the

6 See Eaton and Taylor (for a review), Ozler (199la,b), and Ozler and Tabellini (1991).

'Berg and Sachs (1989) control for variables that are considered to reflect the structural and political features of the borrowers such as share of agriculture in GDP and a measure of income distribution. These variables are available on a cross section basis. Ozler and Tabelini (1991) employ a measure of political instability, which has annual frequency. 
7

potentially endogenous explanatory variables. ${ }^{8}$ We also consider a

specification that uses only the beginning of the sample values for the

exposure variable.

Equation (2) incorporates all country indicators used in equation ( 1 ) and a rescheduling agreement indicator. We expect that the latter variable will influence the occurrence of trading. Almost all countries whose debt has been traded have reached rescheduling agreements with commercial banks, unlike the remaining countries. ${ }^{9}$ In contrast, we do not expect the occurrence of an agreement to affect the magnitude of discounts. Consequently, our prior is that this variable will serve well as an identifying variable. The rescheduling agreement variable we employ for this purpose is a dumy variable that takes the value of one if there was a rescheduling agreement with commercial banks during the previous quarter. ${ }^{10}$

To see how the countries with traded debts differ from the remaining group we compare the means and standard errors of repayment indicators (as presented in Table A.l in the Appendix). Overall, the repayment indicators appear worse for the 21 countries with traded debts.

${ }^{8}$ Dealing with these concerns in an econometrically satisfactory way would require joint estimation of these variables with the discounts. It is extremely difficult to do this with the roughly 400 observations we have.. Furthermore, a very complex system of structural equations would be required.

998 of the countries with debts that are traded during $1986-88$ reached rescheduling agreements with creditor banks between 1978-86. Only 2 of countries whose debts were not traded during 1986-88 did not have any rescheduling agreements with banks since the inception of such formal agreements in the late 1970 s.

10 The mean value of this variable is .10 for the 21 country group with a standard deviation of .3 (over the 12 quarters in 1986-88 period). For the entire group the mean value is .005 with a standard deviation of .07 . 
The mean discount for all countries with traded debts over the period 1986-88 is 47.35 (with a standard deviation of 22.73) and the mean exposure 1s 2.74 billion 1986 US dollars (with a standard deviation of 4.14 ). The data indicate that small borrowers, such as Bolivia, trade at relatively large discounts. (Some summary information on secondary market discounts for the 21 countries with debts that trade at a discount and bank exposures for the 198688 period are in Table A.2, in the Appendix.)

An Important feature of the data is the pattern of secondary market spreads, calculated as the percentage differences between the offer and bid prices quoted in the secondary market. For countries with large discounts, spreads also are quite large, which suggests an investigation of bid prices alone may be potentially misleading. Accordingly, we employ secondary market prices that are calculated using the average of bid and ask prices. ${ }^{11}$ Alternatively, we use the spreads as an explanatory variable in a specification that computes the discounts based on bid prices only.

\subsection{Results}

The primary results of our investigation are that increased bank exposure leads to a decrease in secondary market discounts, and that increased capitalization of banks leads to an increase in discounts, holding countries' repayment prospects constant. In this section, we first discuss the estimation results and then address a number of sensitivity issues.

In Table 1, the results from a maximum likelihood estimation of the discount equation and the probit equation are presented. In the first column we employ a set of base country indicators in both equations. These

11 A couple of countries whose debts have been traded have not been incorporated into the analysis. Liberia and Sudan had extraordinarily high spreads, 37 and 60 respectively. 
indicators are: debt-to-exports ratio, reserves-to-imports ratio, real GNP per capita, and rate of inflation. In addition, the rescheduling agreement. variable is included in the probit equation.

Only debt to exports ratio affects the discounts significantly. In contrast, the occurrence of trading is significantly affected by other country repayment indicators, such as inflation rate and GNP per capita. The finding that most country indicators do not affect secondary market prices is in contrast to the role played by these indicators in studies of credit terms on new loans and in predicting reschedulings. ${ }^{12}$

In column 2 the rescheduling agreement variable is included in both equations. As expected, the agreement variable appears to affect the occurrence of trading in the secondary markets but not the magnitude of discounts.

In column 3, we report results concerning exposure and capital, the variables of primary interest for this study. The findings indicate that exposure has a negative effect, and capital a positive impact on discounts.

Both parameters appear to be statistically significant. ${ }^{13}$

Incorporation of these variables leads to some different results which is evident in a comparison of column 3 with the previous columns. Most important of all is that incorporation of exposure and capital variabless influences the parameter estimates of reserves to imports ratio and the real GNP, suggesting

12 Further investigation of various debt markets and instruments should be undertaken to uncover the sources of this difference. The findings of Stone (1991) are in accordance with ours as the author reports that the changes in the secondary market prices are insensitive to changes in country specific macro economic aggregates, such as exports, reserves and imports.

13 These findings continue to hold irrespective of whether identification is addressed with the rescheduling variable, or simply by relying on functional forms. 
the presence of onitted variables bias in specifications that do not

incorporate these variables. Reserves to imports ratio is now estimated to be a statistically significant determinant of discounts. ${ }^{\text {* }}$

In addition, incorporation of the capital variable detracts from the positive impact of year dummies on discounts reported in the previous specifications. Finally, the magnitude of the constant is increased due to the incorporation of the capital variable. ${ }^{15}$

In column 4 the spread between the bid and ask prices is used as an additional explanatory variable (where the discounts are calculated using the bid prices). The impact of exposure and the impact of capital on discounts are robust to this variation in the specification.

The impacts of exposure and capital on discounts are quite substantial. Consider for example the estimates of -.16 and 6 for exposure and capital respectively. Given our sample these magnitudes imply the following: a 4.1 billion 1986 US dollars increase in the exposure of the large banks to a country is estimated to reduce discounts by 11 cents on the dollar. A 2.7 billion 1986 US dollars increase in the capital of largest U.S. banks is found to increase discounts by nearly 16 cents on the dollar.

\subsection{Sensitivity Analysis}

In order to investigate the robustness of our results, we attempt a number of alternative specifications for the two equations. Our main quantitative results continue to hold.

14 For a discussion of the role of reserves in debt negotiations see 0 'Connel1 (1989). That study suggests that the sign of the reserves variable should be positive as it increases the bargaining power of borrowers vis-a-vis banks, decreasing repayment prospects.

15 The sample mean of this variable (in its log form) is 17.6 . An estimated parameter value near 6.3 explains most of the jump in the constant. 
In the specifications presented above the estimated correlation between the error terms of the two equations is not large and not statistically significant as indicated by $\rho$. This suggests that the evidence for sample selection is not strong. We estimated these specifications with the ordinary least squares (OLS) method for the countries whose debt were traded. The point estimates of all the explanatory variables are smilar to the maximum likelihood estimates (MLE). The standard errors obtained using the OLS procedure are generally smaller than the ones obtained using the MLE procedure. As a consequence, some of the country indicators that are not found statistically significant in the MLE estimation are found significant at low levels of confidence when OLS is used. Debt to export ratio, exposure and capital variables are the only variables that remain significant at high levels of confidence, irrespective of the estimation procedure.

An alternative set of country repayment indicators are incorporated into the analysis. In particular, we replace debt-to-exports and reserves-toimports with debt, reserves and imports all scaled by GNP. Exposure and capital variables are estimated with nearly the same parameter values and statistically significant at high levels of confidence. Debt to GNP ratio is the only country indicator that is a significant determinant of spreads.

We investigate the impact of afternative dummy variable specifications for time affects, such as using quarterly dummy variables, and dropping the dumm variables entirely. None of these changes has any major impact on our general findings.

Exposure to capital ratio is included in the probit equation. The variable is found to have a statistically significant positive impact on the 
occurrence of trading in the market. The results concerning the discount equation are not influenced.

As banks have a significantly high exposure to Brazil and Mexico one might suspect that having these countries in the sample drives our results. Excluding them, however, does not change our qualitative findings. The impact of exposure on discounts is estimated approximately one standard deviation larger with a parameter estimate of -.20 and a standard error of .05.

One might argue that using only one lagged value of the exposure variable does not properly address the potential endogeneity of this variable. We replace the quarterly measure of the exposure variable with simply its beginning of the sample value for each country. This renders it a constant for each country, reflecting the exposure of banks one quarter prior to the beginning of our sample period. All estimates stay nearly the same as our base specification. The exposure is estimated to have a parameter value of -.17 and a standard error of .05 .

Finally, our results continue to hold when we employ exposure of a larger set of banks. In particular, we replace the exposure and capital of the largest 9 banks with the exposure and capital of the largest 24 U.S. banks. The corresponding results are qualitatively similar to the ones reported, but the exposure variable displays a smaller estimated parameter value.

\section{Explanation for the Results}

In this section we suggest that our findings concerning the impact of exposure and bank capital on discounts can be explained by deposit insurance. We also consider other plausible explanations and provide further evidence to support the view that deposit insurance is an explanation of our findings. 


\section{Deposit Insurance}

It has long been recognized that flat rate deposit Insurance and linited liability create incentives for banks to take excessive risk. For example, with regard to banks' overexposure to developing countries, Penati and Protopapadakis (1988) show that federal deposit insurance tends to subsidize risky loans and that the subsidy increases with the riskiness of a bank's loans. The authors suggest that deposit insurance explains the banks' overexposure to developing countries and the earlier underpricing of loans.

Deposit insurance can similarly provide an explanation for the relationship between bank exposure, capital and secondary market discounts. Since the onset of the debt crisis, banks are no longer in the business of making new loans to developing countries. Instead, banks may use the secondary market as a means to alter their developing country loan porfolios. The deposit insurance subsidy can be expected to increase with the riskiness of a bank's developing country loan portfolio. Thus the banks have an incentive to buy additional debts of those countries to which they already are heavily exposed, and they may be willing to pay higher secondary market prices for such loans. ${ }^{16}$ Regulatory capltal affects secondary market prices in a similar fashion. The particularly well capitalized banks are willing to pay less for developing country debt. This is because, for these banks, the expected deposit insurance agency payments are smaller and the cost of obtaining them in case of bankruptcy is higher.

A look at stock market pricing of lender banks' shares provides additional evidence for the views that the value of deposit insurance to banks

16 We do not observe complete specialization. One reason is that the exposure of each bank to a country is restricted not to exceed 158 of bank capital by regulatory agencies. 
is substantial. Several studies have found that developing country exposure has a negative impact on bank share values. ${ }^{17}$ Bank share values are not only determined by expected cash repayments, but in part by the deposit insurance. of course, U.S. banks differ widely in their developing country exposure and capitalization rates, and thus these banks face very different probabilities of ever drawing any funds from the deposit insurance agency. In particular. heavily exposed banks have a more valuable contingent claim on the deposit insurance agency. This suggests that bank share values do not decline linearly with exposure for a given asset base because the value of banks' contingent claim on the deposit insurance agency to some extent softens the negative impact of exposure on bank values.

To investigate whether the relationship between bank stock prices and exposure is in fact non-linear, we estimate the following equation:

$$
\frac{E B-K}{L^{f}+L^{h}}-\alpha_{0}\left(\frac{L f}{L^{f}+L^{h}}\right)+\alpha_{3}\left(\frac{L}{L^{f}+L^{h}}\right)^{2}
$$

where ,

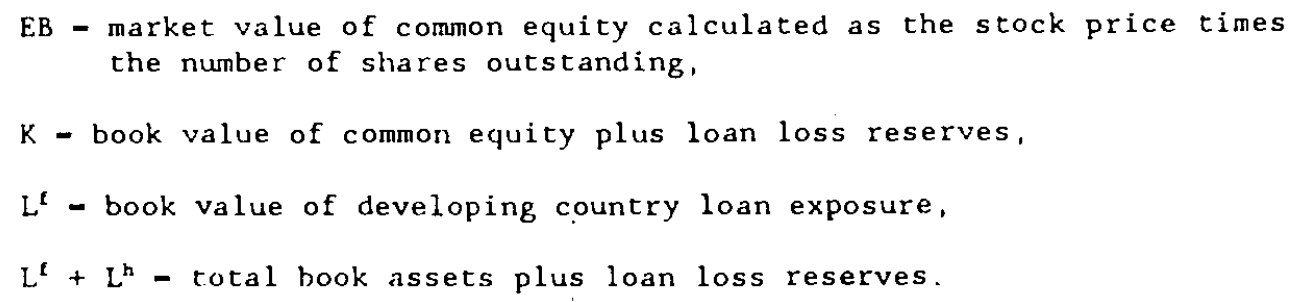

Equation (3) is an accounting identity that restricts the market values of non-developing country assets and bank liabilities to be equal to their book

17 See for example Huizinga (1989) and Sachs and Huizinga (1987). Ozler (1989) finds a negative impact for the $81-83$ crisis period, but a positive impact for the $78-80$ period. 
values. The adjustment involved in equation (3) is allowing the market values of developing country assets to differ from their book values. Hence, (3) relates the deviation of a bank's market value from its book valuc: (divided by assets) to developing country assets as a share of total assets. ${ }^{18}$ The null hypothesis tested with equation (3) is $\alpha_{2}-0$. Rejection of this in favor of a positive $\alpha_{1}$ supports the deposit insurance hypothesis. The sample consists of 23 banks for the year 1987. The $L^{t}$ variable captures the exposure of banks to four large Latin debtor countries: Argentina, Brazil, Mexico, and Venezuela ${ }^{19}$ The regression results are reported in Table 2. The negative estimate of $\alpha_{0}$ indicates that developing country exposure leads to discounts in the stock market valuation of bank assets. The quadratic term is found positive and statistically significant.

The parameter values for equation (3) are used to calculate how bank value declines for a one dollar increase of developing country exposure (the marginal discount). The evidence shows that heavily exposed banks value developing country debt more highly at the margin than the less exposed banks as indicated by less negative marginal discounts in Table 2. The disparity of marginal discounts is consistent with the evidence that especially the smaller

18 See Sachs and Huzinga (1987) for similar estimations. The restrictions incorporated in equation (3) are supported by our data. For instance, the estimate of the market value of non-developing country assets is .995 and it is statistically significant at high levels of confidence, if left to be determined by an equation similar to (3). Estimation of (3) without the quadratic term yields an estimate of $\alpha$ of -0.641 with a t-statistic of $-10.87$

19 Stock price data are for November 31, 1987. All other data are for the end of 1987 . The limitation to four countries is because banks are required to disclose developing country exposure to individual countries only if in excess of $l$ percent of assets. 
regional banks used the secondary market to reduce their developing country exposure during the perlod considered.

\section{Implicit Insurance}

An alternative explanation may stem from the behavior of multilateral lending agencies and creditor country governments. One of the aims of these institutions is to safeguard the stability of the creditor country banking systems. Thus they are more likely to provide lending to debtors to which banks are more heavily exposed if those countries experience payments problems. In this manner these third partles will be enhancing the repayment prospects of those large debtors, providing impliclt insurance to the banks. This could explain the negative relation between exposure and discounts.

While we cannot rule out that implicit Insurance of this kind may be at work, our evidence from the stock market supports the view that deposit insurance is primarily operating. The varying marginal debt values across banks cannot be explained by any differences in treatment of debtor countries by implicit insurance, because banks of different sizes tend to hold developing country loan portfolios of more or less equal country composition. 20

Additional evidence, somewhat cursory in nature, also provides support for the deposit insurance explanation. Average discounts increased from 44.8 to 64.7 between the first quarter of 1986 and the final quarter of 1988, while a large number of the borrowers have been making net transfers to their bank creditors. One potential explanation for this pattern is that net repayments

20 Exposure to Latin America scaled by exposure to all developing countries is approximately the same when the largest banks are compared to the smaller banks: the ratio is $.60, .63, .61$ for the top 9 , next 15 , and the remalning nearly 150 banks respectively at the end of 1987 . 
in the current period simply are not good indicators of future repayment prospects. More likely, the time path of the discounts has resultad flom the strengthening of the regulatory capital position of U.S. banks

Choice of Borrowers

An explanation of the Impact of bank exposure might be argued to lic: in how banks choose among the countries to which they make loans. Large banks may simply have chosen to lend selectively only to higher quality borrowers.

This argument suggests that the exposure variable may just be a proxy for some further unknown omitted variable that measures the creditworthiness of the borrower. We have, however, controlled for several repayment indicators. In particular, we have employed various measures of indebtedness, scaled by countries exports or GNP. Throughout, the impact of the exposure variable remains significant.

A variant of the above argument might be that the large banks may have chosen to sell a smaller share of their high quality loans to syndicate banks. Accordingly, one may suspect that our exposure variable is an empirical proxy for such a concentration variable. But other evidence indicates that exposure and concentration do indeed have independent influences on the secondiry market, as demonstrated in Fernandez and Ozler (1991). The partial correlation between the measure of concentration and our exposure variable is negligible and not statistically significant. Furthermore, the econometric Investigation of secondary market discounts, in Fernandez and ozjer, indicates that exposure continues to play an important role in explaining discounts even after controlling, for the potential impact of concentration. 


\section{Concluding Remarks}

This paper has demonstrated empirically that exposure of large banks has an important and statistically significant negative impact on the sizes of secondary market discounts for developing countiy debt in the 1980s. ${ }^{21}$ The evidence also suggests that bank capital has a strong positive impact on discounts. We indicate that the presence of a deposit insurance agency in lender councries provides an explanation for these results. Evidence on stock market valuation of bank exposure is offered in support of this view.

The results of this paper contribute to policy evaluations in several ways and suggest important areas for future work: First, these results undermine the standard argument for using secondary market prices as guidelines for possible debt relief to developing countries. It is clearly arbitrary to permit debt forgiveness on a basis dependent on characteristics of creditor country financial institutions. A second issue concerns debt buybacks. In several recent papers Bulow and Rogoff (1988a,b) have argued that debt buybacks are harmful to the debtor country because the country ends up paying the average market price to retire marginal debt. The presence of deposit insurance strengthens the argument that the country (in particular a large exposure country) pays too much, since the market price now reflects the average payment per dollar of debt from the country, as well as an implicit subsidy from the deposit insurance agency. ${ }^{22}$ Third, our findings support the

21 As the paper suggests banks recapitalization in the 1980 s implies that insurance is less important in secondary market pricing recently.

22 The Bulow and Rogoff $(1988 \mathrm{a}, \mathrm{b})$ result that the market price rises after a buyback call no longer be considered to be necessarily correct. After the buyback, the average expected payout from the deposit insurance agency may be reduced even if the average expected payment per dollar of debt from the country rises. 
view that deposit insurance blases banks against providing debt forgiveness (Krugman (1990)). The potential gains of debt forgiveness to creditors may be: undervalued by banks with insured deposjts, because forgiveness may lower the expected subsidy provided by deposit insurance. Finally, this research suggests that other factors concerning the regulatory and tax environment in the lender countries or factors that concern the creditors themselves may be potentially important determinants in the secondary market pricing of developing country loans. 
Berg, A. and J. Sachs, "The Debt Crisis: Structural Explanations of Country Performance, " Journal of Development Economics 29, 271-306, 1989.

Bulow, J. and K. Rogoff, "The Buyback Boondoggle," Breokings Papers on Economic Activity 2, 675-698, 1988(a).

"Multilateral Sovereign Debt Reschedulings," International Monetary Fund Staff Papers 35, 644-57, 1988(b).

Classens, S., I. Diwan, K, Froot, P. Krugman, "Market Based Debt Reductin for Developing Countries: Principles and Prospects" mimeo, 1990

Cohen, D., "Is the Discount on the Secondary Market a Case for LDC Debt Rellef?," PPR Working Paper 132, World Bank, 1988.

Fernandez, R. and S. Ozler, "Debt Concentration and Secondary Market Prices : A Theoretical and Empirical Analysis" NBER Working Paper No: $3654,1991$.

Froot, K. "Buybacks, Exit Bonds, and the Optimality of Debt and Liquidity Relief" International Economic Review.

Hajivassiliou, V., "Do Secondary Markets Believe In Life After Debt?" in $H$. Ishrat and I. Diwan (eds.) Dealing with the Debt Crisis, World Bank, Washington D.C., 276-292, 1989.

Heckman, J., "Sample Selection Bias as a Specification Error," F.conometrica Vol 47, no 1, 153-161, 1979.

Huizinga H., "The Commercial Bank Claims on Developing Countries: How Have Banks Been Affected?" in H. Ishrat and I. Diwan (eds.) Dealing with the Deht Crisis, World Bank, Washington, D.C., 129-143, 1989.

Kruginan, P., "Bank Regulation and LDC Debt", MIT mimeo, 1990.

O'Connell A. S., "A Bargaining Theory of International Reserves", mimeo August 1989 .

Obstfeld, M. "Capital Mobility in the World Economy: Theory and Measurement", in K.Brunner and A.H. Meltzer (eds) Carnegle-Rochester Conference Serles on Public Policy, Spring 1986, 24.

Ozler, S., "On the Relation Between Reschedulings and Bank Value," American Economic Review 79, 1117-1131, 1989. 
"Evolution of Credit Terms: An Empirical Study of Commercial Bank Lending to Developing Countries," forthcoming Journal of Development Economics 1991(a).

- "Have Conmercial Banks Ignored History ?" UCLA mimeo, 1991(b).

, and Tabellini, "External Debt and Political Instability". NBER Working Paper, No:3772, July 1991.

Penati, A., and A. Protopapadakis, "The Effects of Implicit Deposit Insurance on Banks' Portfolio Cholces with an Application to International 'Overexposure'," Journal of Monetary Economics 21, $107-126,1988$.

Quarterly Review on Financial Flows to Developing Countries, World Bank, 1989.

Purcell, J. and D. Orlanski, "Developing Country Loans: A New Valuation Model for Secondary Market Trading," Corporate Bond Research, Salomon Brothers Inc., New York, June 1988

Sachs, J. and H. Huizinga, "U.S. Commercial Banks and the DevelopingCountry Debt Crisis," Brookings Papers on Economic Activity, 1987.

Stone, M. "Sovereign Debt Secondary Market Returns," Journal of International Money and Finance, 1991. 
Table 1. Maximum Likel thood Estimates of Discounts and Trading

Nobs: Traded in secondary mkt -225 , Not traded -208

Variable

(1)

(2)

(3)

\begin{tabular}{|c|c|c|c|c|}
\hline Debt/Exports ${ }^{2}$ & $\begin{array}{c}0.0012 \star \star \\
(0.0004)^{3}\end{array}$ & $\begin{array}{l}0.0013 \star \star \\
(0.0004)\end{array}$ & $\begin{array}{l}0.0011 * \star \\
(0.0004)\end{array}$ & $\begin{array}{l}0.0008 \star \star \\
(0.0004)\end{array}$ \\
\hline Reserves/Import & $\begin{array}{c}0.0009 \\
(0.0009)\end{array}$ & $\begin{array}{c}0.0010 \\
(0.0009)\end{array}$ & $\begin{array}{l}0.0019 \star \\
(0.0009)\end{array}$ & $\begin{array}{c}0.0015 * \\
(0.0007)\end{array}$ \\
\hline Real GNP & $\begin{array}{l}-0.1855 \\
(0.1349)\end{array}$ & $\begin{array}{l}-0.1868 \\
(0.1358)\end{array}$ & $\begin{array}{l}-0.0239 \\
(0.1387)\end{array}$ & $\begin{array}{l}-0.01097 \\
(0.1226)\end{array}$ \\
\hline Inflation & $\begin{array}{c}0.0070 \\
(0.0103)\end{array}$ & $\begin{array}{c}0.0084 \\
(0.0109)\end{array}$ & $\begin{array}{c}0.0108 \\
(0.0112)\end{array}$ & $\begin{array}{c}0.0084 \\
(0.0074)\end{array}$ \\
\hline $\begin{array}{c}\text { Rescheduling } \\
\text { Agreement }\end{array}$ & & $\begin{array}{c}0.2335 \\
(0.3485)\end{array}$ & & \\
\hline Year - 1987 & $\begin{array}{c}0.1436 \\
(0.1007)\end{array}$ & $\begin{array}{c}0.1377 \\
(0.1009)\end{array}$ & $\begin{array}{l}-0.3501 \\
(0.2109)\end{array}$ & $\begin{array}{l}-0.3238 \\
(0.1925)\end{array}$ \\
\hline Year - 1988 & $\begin{array}{c}0.5015 \\
(0.1660)\end{array}$ & $\begin{array}{c}0.5113 \\
(0.1689)\end{array}$ & $\begin{array}{l}-0.3374 \\
(0.2985)\end{array}$ & $\begin{array}{l}-0.2082 \\
(0.2692)\end{array}$ \\
\hline Exposure & & & $\begin{array}{l}-0.1666 \star \star \\
(0.0514)\end{array}$ & $\begin{array}{l}-0.1228 * \star \\
(0.0406)\end{array}$ \\
\hline Capital & & & $\begin{array}{l}6.2607 \star \star \\
(2.1679)\end{array}$ & $\begin{array}{l}4.8404 * \star \\
(1.9162)\end{array}$ \\
\hline Bid-Ask Spread & & & & $\begin{array}{l}0.0381 * \star \\
(0.0130)\end{array}$ \\
\hline Constant & $\begin{array}{c}3.0618 \\
(0.3181)\end{array}$ & $\begin{array}{c}2.9715 \\
(0.3347)\end{array}$ & $\begin{array}{r}-105.1740 \\
(38.2666)\end{array}$ & $\begin{array}{l}-81.1875 \\
(33.7335)\end{array}$ \\
\hline
\end{tabular}


Table 1. (cont.)

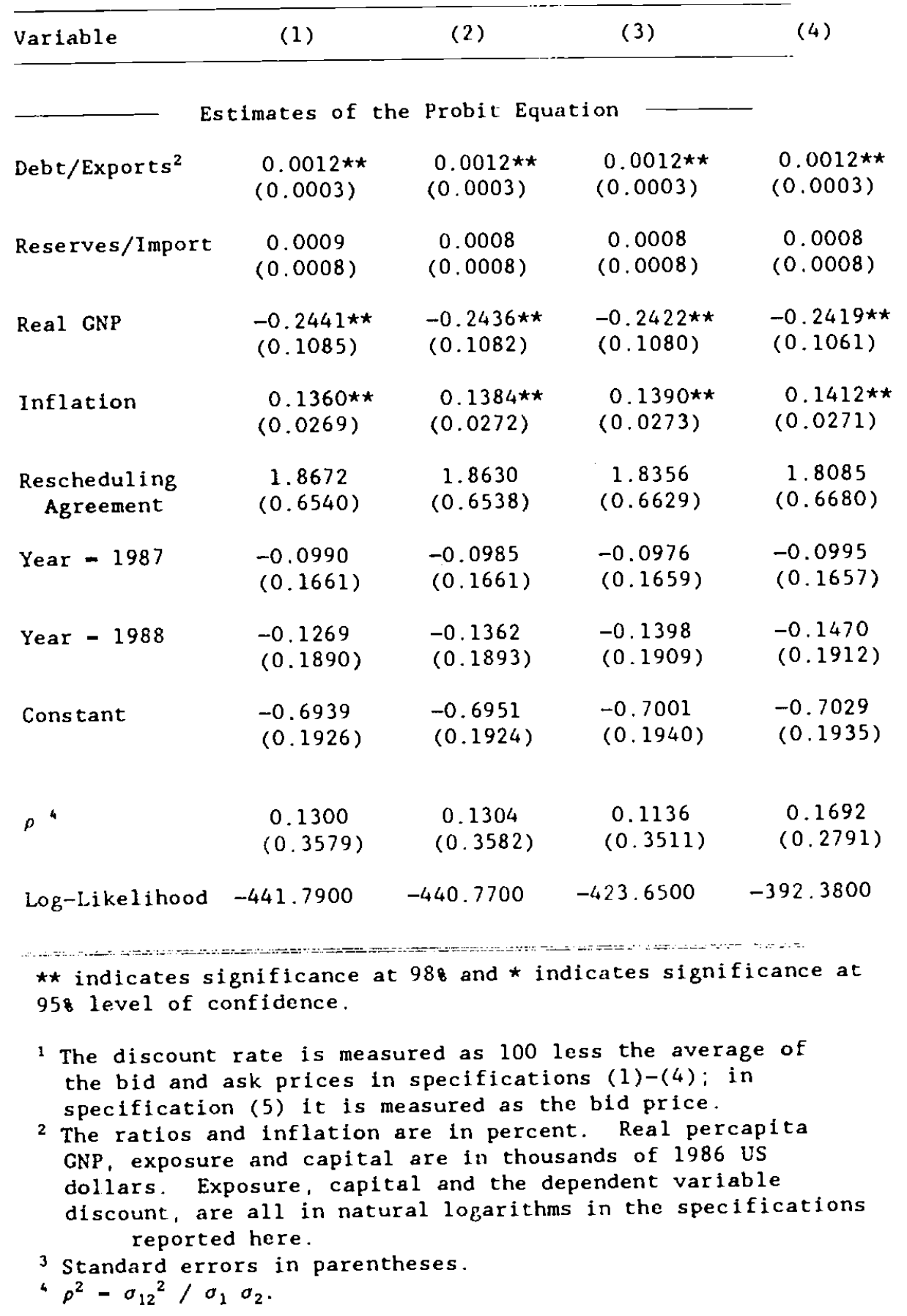


Table 2. OLS Estimates of Stock Market Valuation

A. Estimated equation (3)

\begin{tabular}{cccc}
$\alpha_{0}$ & $\alpha_{1}$ & Nobs. & Adj. R-square \\
\hline $\begin{array}{r}-1.057 \\
(-6.43)\end{array}$ & $\begin{array}{r}7.099 \\
(2.67)\end{array}$ & 23 & 0.46
\end{tabular}

B. Marginal Discounts for U.S. Banks ${ }^{1}$

Bank

Exposure to

Latin four

(millions)

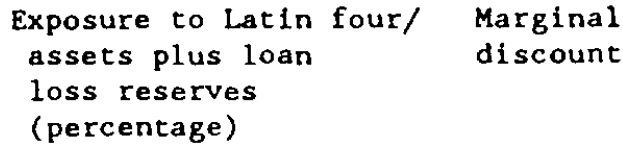

\begin{tabular}{lrrr}
\hline & & & \\
Citicorp & 9,100 & 4.37 & -0.41 \\
Chase Manhattan & 6,440 & 6.32 & -0.31 \\
BankAmerica & 7,025 & 7.31 & -0.26 \\
Chemical & 4,401 & 5.48 & -0.36 \\
J.P. Morgan & 4,350 & 5.64 & -0.35 \\
Man. Hanover & 6,571 & 8.65 & -0.19 \\
Sec. Pacific & 1,558 & 2.09 & -0.53 \\
Bankers Trust & 2,778 & 4.81 & -0.39 \\
First Interstate & 1,047 & 2.01 & -0.54 \\
First Chicago & 2,237 & 4.89 & -0.39 \\
Wells Fargo & 1,542 & 3.39 & -0.47 \\
PNC Financial & 322 & 0.87 & -0.60 \\
Bank of Boston & 851 & 2.44 & -0.52 \\
Mellon & 1,111 & 3.51 & -0.46 \\
Bank of New Eng. & 261 & 0.87 & -0.60 \\
First Bank System & 307 & 1.13 & -0.59 \\
Irving Bank & 1,391 & 5.74 & -0.34 \\
Bank of N.Y. & 533 & 2.27 & -0.52 \\
Republic N.Y. & 455 & 2.01 & -0.54 \\
Norwest & 285 & 1.35 & -0.57 \\
Midlantic & 261 & 1.45 & -0.57 \\
National City & 196 & 1.29 & -0.58 \\
Mercantile Bank & 188 & 2.71 & -0.50 \\
& & &
\end{tabular}

1 Marginal discounts are for total developing country exposure of U.S. banks.

Sources: 10-K reports, Salomon Brothers' Review of Bank Performance, and the Wall Street Journal. 


\section{APPENDIX}

Table A.1. Sample Characteristics

Country Indicators (1986-1988)

\begin{tabular}{|c|c|c|c|c|}
\hline & \multicolumn{4}{|c|}{ For Countries Whose Assets Are: ${ }^{1}$} \\
\hline & \multicolumn{2}{|c|}{ Traded } & \multicolumn{2}{|c|}{ Not Traded } \\
\hline & Mean & $\begin{array}{l}\text { Standard } \\
\text { Deviation }\end{array}$ & Mean & $\begin{array}{l}\text { Standard } \\
\text { Deviation }\end{array}$ \\
\hline Debt/Exports & 4.02 & 2.47 & 2.62 & 2.22 \\
\hline Reserves/Imports & 1.20 & 1.00 & 1.03 & 0.74 \\
\hline Real GNP & 1.30 & 0.76 & 2.03 & 2.05 \\
\hline Inflation & 0.10 & 0.13 & 0.02 & 0.03 \\
\hline Debt/GNP & 0.71 & 0.34 & 0.40 & 0.16 \\
\hline Reserves/GNP & 0.22 & 0.18 & 0.39 & 0.64 \\
\hline Imports $/ 6$ & 0.22 & 0.11 & 0.37 & 0.37 \\
\hline
\end{tabular}

1 The countries whith debt traded in the secondary market are: Argentina, Bolivia, Brazil, Chile, Colombia, Costa-Rica, Dominican Republic, Ecuador, Honduras, Ivory Coast, Jamaica, Mexico, Morocco, Panama, Peru, Philippines, Turkey, Uruguay, Venezuela, Yugoslavia, Zaire.

The remaining countries in our sample are: Cameroon, Egypt, El Salvador, Ethiopia, Greece, Hungary, India, Indonesia, Israel, Jordan, Kenya, Korea, Pakistan, Paraguay, Portugal, Singapore, Sri Lanka, Thailand, Trinidad and Tobago, Tunisia.

Variable Definitions:

(All variables except GNP and debt are quarterly.)

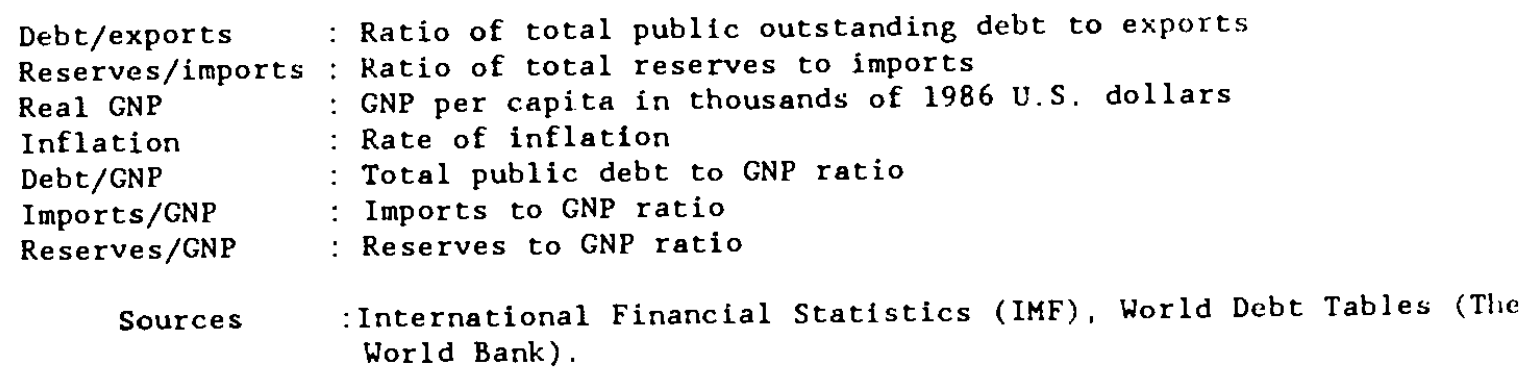


Table A.2. Secondary Market D1scounts and Bank Exposure ${ }^{1}$

\begin{tabular}{lrrrr} 
Country & Discount & Deviation & Spread & \multicolumn{1}{c}{ Exposure } \\
\cline { 2 - 4 } Argentina & 53.34 & 18.75 & 2.82 & 6.52 \\
Bolivia & 91.31 & 2.00 & 18.32 & 0.04 \\
Brazil & 41.01 & 13.68 & 2.42 & 15.80 \\
Chile & 36.94 & 4.75 & 2.43 & 3.89 \\
Colombia & 23.93 & 10.18 & 2.00 & 1.45 \\
Costa Rica & 70.67 & 15.16 & 9.49 & 0.19 \\
Dominican Republic & 65.42 & 11.90 & 7.05 & 0.28 \\
Ecuador & 54.31 & 19.42 & 4.30 & 1.16 \\
Honduras & 67.29 & 8.42 & 8.46 & 0.05 \\
Ivory Coast & 43.95 & 21.64 & 5.56 & 0.28 \\
Jamaica & 59.72 & 4.99 & 9.42 & 0.11 \\
Mexico & 46.74 & 5.10 & 2.38 & 13.19 \\
Morocco & 38.77 & 9.44 & 3.16 & 0.59 \\
Panama & 49.14 & 21.37 & 5.97 & 0.51 \\
Peru & 87.80 & 6.41 & 18.63 & 0.54 \\
Philippines & 40.50 & 8.29 & 3.03 & 3.32 \\
Turkey & 2.54 & 0.65 & 1.46 & 1.09 \\
Uruguay & 36.12 & 4.73 & 2.91 & 0.67 \\
Venezuela & 35.96 & 12.33 & 2.14 & 6.02 \\
Yugosiavia & 34.91 & 15.99 & 2.46 & 1.23 \\
Zaire & 77.91 & 2.80 & 13.88 & 0.01
\end{tabular}

1 Discount is the mean of (100-bid price) for the 1986-88 period. Deviation is the standard deviation of the discounts. Spread is calculated as the percentage difference between the bid and ask prices.

Exposure is for the nine largest U.S. banks in $\$$ billion.

\footnotetext{
Sources: Indicative Prices for less Developed Country Bank Loans (Salomon Brothers), and Country Exposure Lending Survey (Federal Financial Institutions Examination Council).
} 